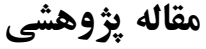 \\ مجله دانشعاه علوم بز شكى رفسنجان \\ دوره 19، دى \\ مدليابى اعتياد به اينترنت بر اساس حساسيت بين فردى و تعارض زناشويى والدين با

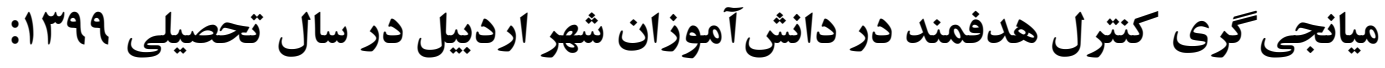

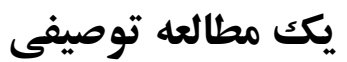

سجاد بشريور'، شيرين احمدى'، فاضله حيدرى"

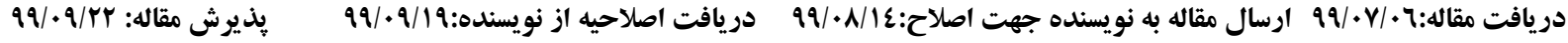
زمينه و هدف: حساسيت به تعاملات بين فردى و تعارضات زناشويى نقش مهمى در كرايش به اعتياد اينترنت فرزندان دارد. يزوهش حاضر با هدف مدليابى اعتياد به اينترنت بر اساس حساسيت بين فردى و تعارض زناشويى والدين با ميانجى كنترل هدفمند در دانشآموزان انجام كرفت.

مواد و روشها: روش يزوهش حاضر توصيفى مىباشد. جامعه آمارى شامل كليه دانشآموزان دوره اول و دوم متوسطه شهر

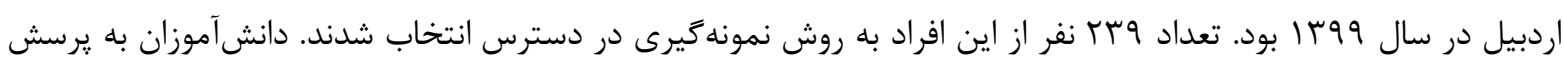
نامههاى اعتياد به اينترنت، كنترل هدفمند، حساسيت بين فردى و تعارضات زناشويى والدين پاسخ دادند. براى تجزيه و تحليل دادهها از ضريب همبستخى Pearson و مدلسازى معادلات ساختارى استفاده شد.

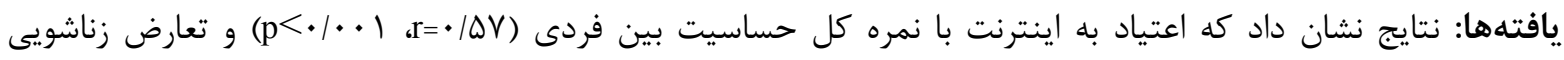

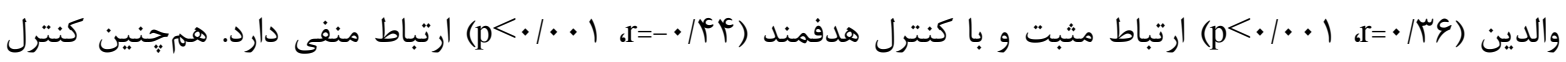

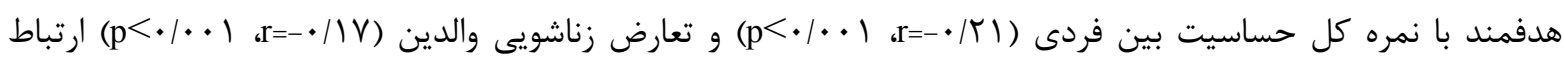
منفى دارد. شاخصهاى برازش مدل نيز حساسيت بين فردى و تعارضات زناشويى بر اعتياد به اينترنت را با ميانجى كنترل هدفمند تأييد كرد. نتيجه كيرى: نتايج اين يزوهش مىتواند در ايجاد برنامههاى كاربردى و كاركاههاى آموزشى براى نوجوانانى كه داراى اعتياد

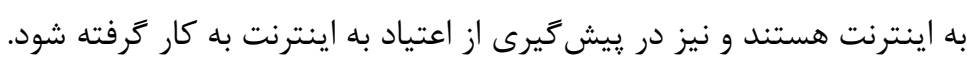
وازههاى كليدى: اعتياد به اينترنت، كنترل هدفمند، حساسيت بين فردى، تعارضات زناشويى والدين، دانشآموزان، اردبيل

1- ـ (نويسنده مسئول) استاد كروه روانشناسى، دانشكده علوم تربيتى و روانشناسى، دانشكاه محقق اردبيلى، اردبيل، ايران

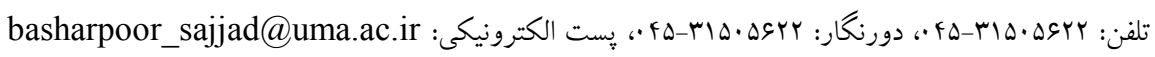

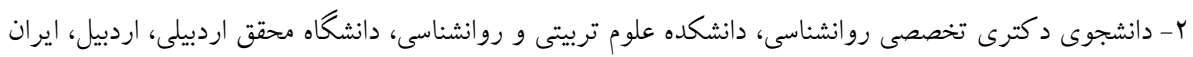

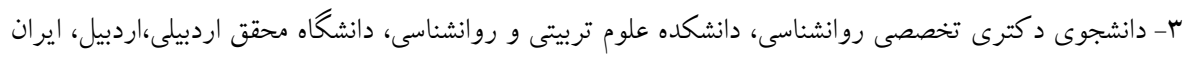


نوجوانان همبستكى مثبت و معنىدارى وجود دارد [ع].

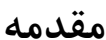

علاوه بر اين، معتادان به اينترنت احتمالاً روابط بين فردى ضعيف را حفظ مى كنند كه اين امر ممكن است به احساس تنهايى بيشتر در آنها منجر شود [V]

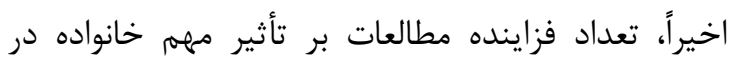
اعتياد جوانان به اينترنت به طور خاص يرداخته است. مطالعات نشان داده است كه تعارض زناشويى والدين اعتياد شديد به اينترنت در (Parents Marital Conflict) جوانان را پيشبينى مىكند [1-9]. محيط خانوادگى نامناسب مىتواند احساس امنيت نوجوان را كاهش داده و به طور معنىارى خطر مشكلات روانشناختى و رفتار را افزايش دهد. نظريه سيستمهاى خانواده Bowen فرض مى كند كه خانواده يك واحد هيجانى بنيادى است كه واجد ويزگى نكَدارنده تعادل حياتى آن سيستم است. زمانى كه والدين با همديكر تعارض داشته باشند، اين سيستم مختل مىشود. هنغامى كه كود كان بىثباتى موجود در سيستم كه به دليل تعارض والدين ايجاد شده است را ادراك مى كنند، بيشتر ممكن است به رفتارهاى مشكلزا بيردازند [.1]. همسو با اين نظريه، جندين مطالعه تجربى نشان دادهاند كه تعارض زناشويى والدين مىتواند در اعتياد به اينترنت نقش داشته باشد [ץ |-11]]. مطالعه Ko و همكاران نشان داد كه تعارض زناشويى والدين قوىترين پِيشبينى كننده اعتياد به اينترنت مىباشد [ـ1 [1]. Gao و همكاران نشان دادند كه تعارض زناشويى والدين بر اعتياد به اينترنت تأثير مستقيمى دارد و اين اثر به وسيله اضطراب و افسردىى نيز ميانجى

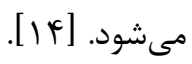

اعتياد به اينترنت (Internet addiction) توسط Young به عنوان عدم توانايى جلوگيرى از استفاده بيش از حد از اينترنت با صرف زمان ناجيز بودن اتصال به اينترنت، وجود تحريكيذيرى شديد و يرخاشگرى در هنگام محروميت و ايجاد اختلال در زندگى شخصى، خانوادگى، اجتماعى و شغلى فرد تعريف شده است. همرجنين نوجوانان بيش از بزرگىسالان مستعد ابتلاء به اعتياد به اينترنت هستند [1]. اعتياد به اينترنت طى دو دهه اخير مورد توجه محققان و متخصصان قرار گرفته است و به طور گستردهاى براى تحقيق و كشف اهداف علائم اعتياد در افراد مورد استفاده قرار گرفته است. استفاده روزمره از اينترنت به ويزه در جمعيت نوجوانان و جوانان بسيار قابل توجه است و علاوه بر مزاياى بىشمار، استفاده از اينترنت خطرات زيادى از جمله رفتار اعتيادآور به همراه دارد [r]. از سازمهاى مورد بررسى در يزوهش حاضر كه به نظر مى رسد با اعتياد به اينترنت ارتباط دارد حساسيت بين فردى مىباشد. حساسيت بين فردى (Interpersonal Sensitivity) شامل تجربيات عاطفى مىباشد كه به عنوان احساس حقارت، عدم كفايت شخصى و روحيه ضعيف تعريف مىشود [ץ]]. افرادى كه داراى حساسيت بين فردى بالايى هستند به احتمال زياد به تلفنهاى همراه اعتياد پيدا مى كنند [F]. مطالعه طولى بر روى نوجوانان تأثير حساسيت بين فردى بر اعتياد به اينترنت را نشان داده است [ه]]. Chen و همكاران در مطالعات خود نشان دادند بين اعتياد به اينترنت و استفاده اعتيادى از تلفن همراه با مشكلات بين فردى در 
[r][]. كنترل هدفمند به عنوان متغير ميانجى بهصورت

غيرمستقيم با تعارض والدين و استفاده اعتيادى از اينترنت در نوجوانان ارتباط دارد و پيشبينى كننده عملكرد بين

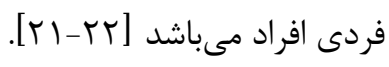

با توجه به اينكه امروزه اينترنت يكى از مهمترين ييشرفتهاى بشر در دهلهاى اخير به شمار مىرود و زندگى ما را از جنبههاى مختلفى متحول ساخته و بسيارى از تغييرات مثبت غيرقابل انكار را به وجود مى آورد. با اين حال، در همان زمان باعث عواقب منفى از جمله اعتياد به اينترنت شده است[rr]. بر اين اساس يزوهش حاضر با هدف مدليابى اعتياد به اينترنت بر اساس حساسيت بين فردى و تعارض زناشويى با ميانجى مدل مفهومى زير (نمودار () انجام گرفت.
به نظر مىرسد كنترل هدفمند (Effortful Control) يكى از عوامل اساسى زمينهساز اعتياد به اينترنت است. كنترل هدفمند به كاركرد توجه دستعاههاى اجرايى از جمله فعالسازى توجه مناسب و سركوب پِاسخهاى نامناسب اشاره

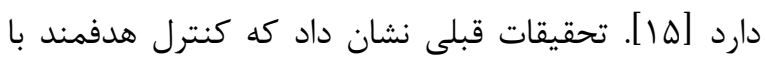
اعتياد به اينترنت [ع|] و اعتياد به تلفن همراه ارتباط دارد [IV] [IV [نترل هدفمند كم، به عنوان يكى از مهمترين عوامل مرتبط با رفتارهاى اعتيادى از جمله اعتياد به اينترنت در نوجوانان شناخته شده است [1/]. Wang و همكاران در مطالعات خود گزارش دادند بين اعتياد به اينترنت و كنترل هدفمند ارتباط منفى و معنىدارى وجود دارد [9 1 ] و كنترل هدفمند ضعيف تا حدى مىتواند استفاده مشكلساز نوجوانان به ويزه در بين يسران از اينترنت را توضيح دهد

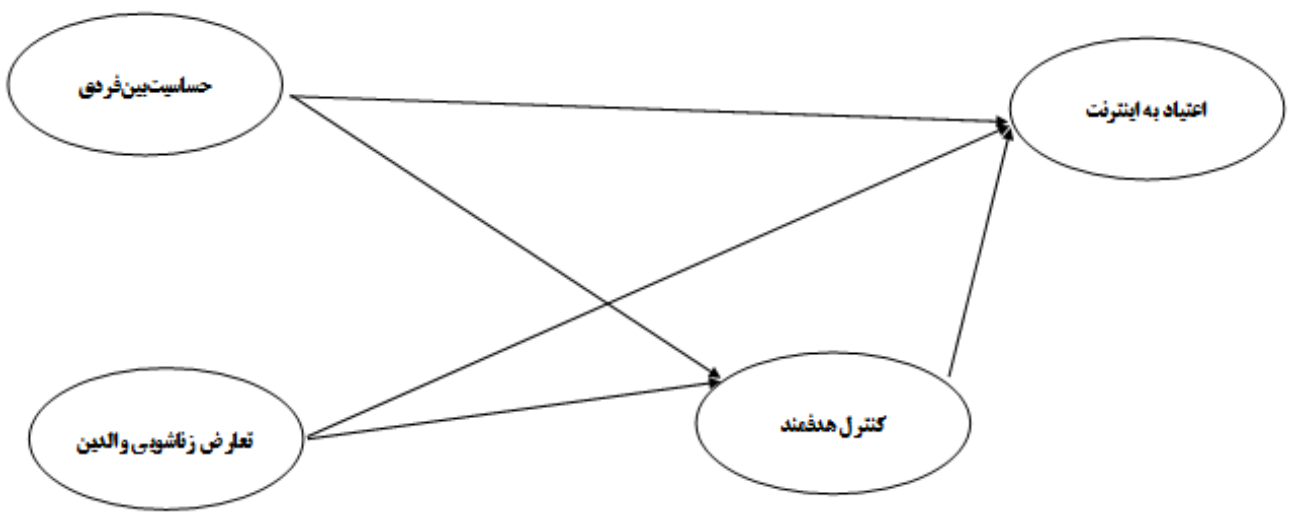

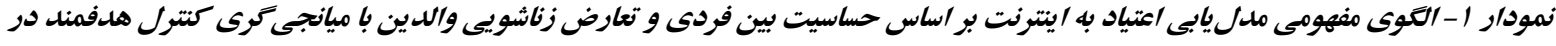
دانشآموزان شهر اردبيل دو سال تحصيلى 19

علوم يزشكى اردبيل تصويب شده است. جامعه آمارى

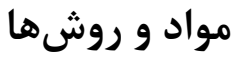
يزوهش حاضر را كليه دانشآموزان دوره اول و دوم متوسطه شهر اردبيل در سال 9¥ا تشكيل دادند. از آنجايى كه بهزعم بسيارى از يزوهشگران حداقل حجم نمونه لازم در روش مطالعه حاضر از لحاظ هدف كاربردى و از نظر ماهيت و روش توصيفى مىباشد كه با كد اخلاق IR.ARUMS.REC.1399.407 در كميته اخلاق دانشعاه 
\&ه • إ مدل يابى اعتياد به اينترنت بر اساس حساسيت بين فردى و تعارض زناشويى والدين ...

اساس ملاكهاى اختلال قماربازى بيمار گون طراحى شدهاند جرا كه گمان مىرود اختلال اعتياد به اينترنت شباهت زيادى با اختلال قماربازى بيمارگون دارد. اين برسشنامه داراى · r سؤال است و تعيين مىكند كه آيا استفاده بيشازحد از اينترنت بر جنبههاى مختلف زندگى فرد اثر كذاشته است يا خير و با استفاده از مقياس له درجهاى

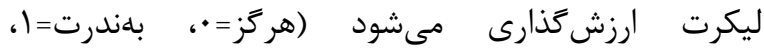

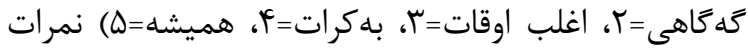

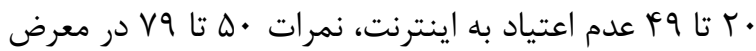
اعتياد به اينترنت و نمرات •^ تا • · اعتياد به اينترنت را نشان مىدهد. در مطالعه Young و همكارش، اعتبار درونى يرسشنامه بالاتر از 9r/•ذكر شده و اعتبار به روش بازآزمايى نيز معنى دار كزارش شده است [عr]. Widyanto و همكارش در مطالعه خود روايى صورى اين يرسشنامه را بسيار بالا ذكر كردهاند [rv]. در ايران اعتبار و ק.يايى اين آزمون توسط Alavi و همكاران بهدست آمده است كه يايايى باز آزمايى آن AT/•، همسانى درونى از طريق آلفاى كرونباخ

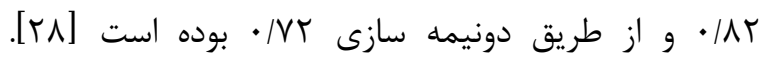
ضريب يايايى آن در يزوهش حاضر • 9/ • بهدست آمد. فرم كوتاه مقياس خلقوخوى بزرَسال: اين مقياس توسط Rothbart و همكاران در سال ... . ساخته شده و مشتمل بر VV آيتم مىباشد كه شامل f أ بعد عاطفه منفى، كنترل هدفمند، برونگرايى/ شادخويى و جهت حساسيت مىباشد [9ץ]. بعد كنترل هدفمند اين مقياس كه در اين يزوهش مورد استفاده قرار گرفت شامل ب خرده مقياس كنترل توجه (ه سؤال)، كنترل بازدارى (V سؤال) و
مدلسازى معادلات ساختارى . . مىباشد [Yr]، حجم نمونه در يزوهش حاضر نيز با در نظر گرفتن احتمال افت نمونهها، • له نفر در نظر كرفته شد كه بعد از حذف داده هاى مخدوش qجr يرسشنامه وارد تحليل آمارى شد. روش نمونه گيرى مورد استفاده نيز در دسترس بود. روش جمعآورى اطلاعات به اين صورت بود كه با توجه به وضعيت كرونا و شرايط قرنطينه و عدم دسترسى به دانش آموزان بلهورت حضورى، يرسشنامهها در دو بخش كه بخش اول شامل اطلاعات جمعيت شناختى (سن، جنس، شغل يدر و وضعيت اقتصادى) بود و بخش دوم شامل يرسشنامهاى اعتياد به اينترنت، كنترل هدفمند، حساسيت بينفردى و تعارض زناشويى والدين در نرمافزار يرس لاين طراحى و به صورت آنلاين از طريق كذاشتن لينك آنها در گروههاى كلاسى و كانالهاى تلكرام، گروههاى واتساب مدارس مقاطع متوسطه از تاريخ ه ارديبهشت تا ها مرداد در اختيار آزمودنىها قرار داده شد تا دانشآموزانى كه تمايل به شركت در يزوهش داشتند به سؤالات پاسخ دهند كه بعد از وارد كردن دادهها به SPSS نسخه له و بعد از حذف دادههاى يرت، وبr يرسشنامه وارد تحليل آمارى شد. معيارهاى ورود تمايل به شركت در يزوهش و دانشآموز بودن و معيار خروج عدم تمايل به شركت در يزوهش بود. يرسشنامههاى اعتياد به اينترنت، حساسيت بين فردى و تعارض زناشويى والدين به صورت خلاصه عبارت بودند از: مقياس اعتياد به اينترنت: اين :يرسشنامه توسط [roung [اخته شد و در زمينه سنجش اعتياد اينترنتى مورد استقبال بسيارى قرار گرفت. سؤالات اين آزمون بر 
روش آلفاى كرونباخ AVV • به دست آمد و روايى آن نيز تأييد

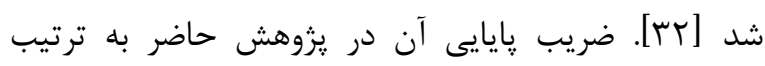

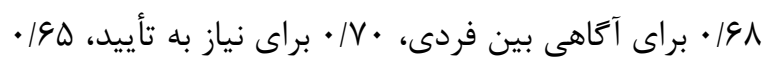
براى اضطراب جدايى، سY/ • براى كمرويى و 99/• براى خود درونى شكننده و ז9/• براى نمره كل حساسيت بين فردى

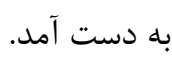

مقياس ادراك كودكان از تعارض بين والدين: اين

مقياس توسط Čnernja و همكاران ساخته شده است [بr]. اين مقياس يك ابزار ب بؤالى است كه ادراك كودكان سنين مدرسه از تعارض زناشويى والدين خود را در سه خرده مقياس ارزيابى مى كند: ويزگكىهاى تعارض، خود سرزنشى و تهديد. در هر سؤال كودكان انتخاب مى كنند كه آيا آن سؤال در مورد آنها درست است (؟)، تا حدى درست است فئ (1)، يا درست نيست (·). اين مقياس در تعداد زيادى از مطالعات مورد استفاده قرار كرفته و پايايى بازآزمايى آن از

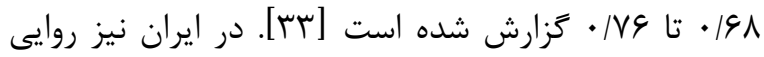
مقياس ادراك كودكان از تعارض بين والدين با روش آمارى تحليل عاملى تأييدى مورد قبول قرار كرفت و پايايى خرده مقياسهاى تعارض، تهديد و سرزنش خود با روش آلفاى

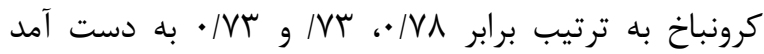

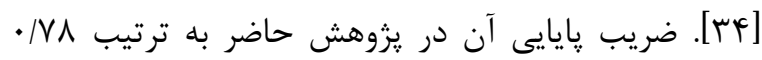
براى ويزگكىهاى تعارض، 19/· براى خودسرزنشى، 99|. براى تهديد و \&1/· براى نمره كل تعارض بين والدين به

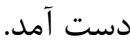

دادههاى جمعآورى شده در اين يزوهش با استفاده از

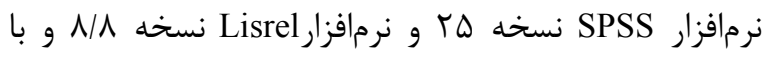

كنترل فعاليت (Vؤ Vوال) مىباشد. تمام سؤالات اين يرسش

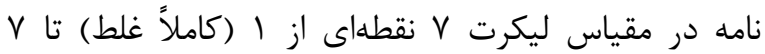
(كاملاً درست) درجهبندى مىشود. عاملهاى اين مقياس همبستَى بالايى با مقياسهاى ها هنج عامل بزرك شخصيت دارد. همرجنين مشخص شده است كه سنجههايى كه زمان واكنش را مىسنجند، همبستخى قابل ملاحظهاى با عامل كنترل هدفمند دارند. ضرايب آلفاى كرونباخ خرده مقياسهاى اين آزمون در دامنه VD/• تا اN/ • كزارش شده است [9r]. اين ضرايب بر روى آزمودنىهاى يك نمونه

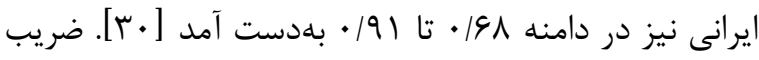
يإيايى آن در يروهش حاضر به ترتيب له / • براى كنترل توجه، ז / • براى كنترل بازدارى، هو| • براى كنترل فعاليت و و • براى نمره كل كنترل هدفمند بهدست آمد. مقياس حساسيت بين فردى: مقياس حساسيت بين فردى توسط Boyce و همكارش براى سنجش ابعاد اساسى مفهوم حساسيت بين فردى ابداع شد. اين مقياس وب سؤال و ه خرده مقياس دارد كه هاسخ به هر عبارت آن در يك مقياس ليكرت \& درجهاى مىباشد. اين عامل شامل آكاهى بين فردى، نياز به تأييد، اضطراب جدايى، كمرويى و خود درونى شكننده مىباشد. مطالعات در خصوص حساسيت بين فردى شواهد روانسنجى خوبى را به همراه داشته است، به طورى كه همسانى درونى و پايايى بازآزمايى و اعتبار همركرا و واكراى بالايى تزارش شده است. Boyce و همكاران ضريب پايايى بازآزمايى هA/· براى نمره كل و ضرايبى در دامنه

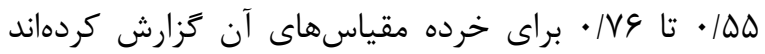
[اب]. در ايران نيز بإيايى مقياس حساسيت بين فردى بال 
1/ 1/ سال در اين يزوهش شركت داشتند. از لحاظ شغل

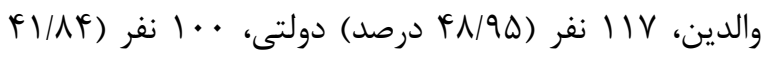
درصد) آزاد، r ن نفر (• 9/T درصد) بى كار بودند و از لحاظ

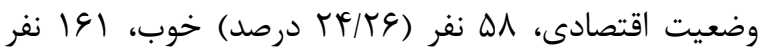

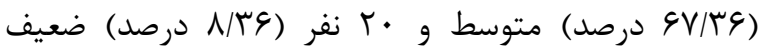

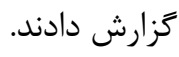

نتايج جدول ل، ميانغين و انحراف معيار متغيرهاى اعتياد به اينترنت، كنترل هدفمند، حساسيت بين فردى و تعارض زناشويى والدين و مؤلفههاى آنها را نشان مىدهد.
روشهاى آمار توصيفى (ميانگين و انحراف معيار) و آمار استنباطى (آزمونهاى همبستخى مearson) و مدلسازى معادلات ساختارى تحليل شد. سطح معنىدارى در آزمونها

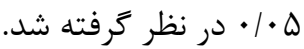

\section{نتايج}

تعداد وسr دانشآموز در اين يزوهش شركت داشتند كه و انحراف معيار سنى זr/ آ سال و درصد) دختر با ميانخين سنى |f/9|| و انحراف معيار سنى جدول ا - ميانتين و انحراف معيار نمرات شركت كنندهها دو اعتياد به ايتترن، كتترل هدفمنلد، حساسيت بين فردى، تعارض زناشويع والدين در

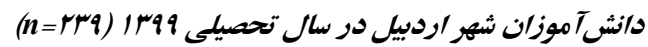

\begin{tabular}{|c|c|c|c|c|c|}
\hline 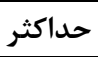 & حداقل - & انحراف معيار & ميانغين & متغير ها & \\
\hline$V^{f}$ & r. & $I T / T r$ & ए9/99 & اعتياد به اينترنت & اعتياد به اينترنت \\
\hline |r| & $\Delta \cdot$ & $\mid F / \Delta T$ & $V V / T V$ & كنترل هدفمند (نمره كل) & \multirow{4}{*}{ كنترل هدفمند } \\
\hline ro & $\wedge$ & $\Delta / \cdot 1$ & 19/Ar & كنترل توجه & \\
\hline $4 q$ & ו & $\Delta / \wedge 9$ & rN/A9 & كنترل بازدارى & \\
\hline iv & 19 & $81 \cdot \cdot$ & TN/9D & كنترل فعاليت & \\
\hline IFD & pr & Tr/9q & $V \wedge / \Delta \cdot$ & حساسيت بين فردى (نمره كل) & \multirow{6}{*}{ حساسيت بين فردى } \\
\hline r & v & $4 / 91$ & $|F / \Delta|$ & آكاهى بين فردى & \\
\hline ו & $\wedge$ & $\Delta / \Delta \Lambda$ & IN/FT & نياز به تأييد & \\
\hline ro & $\wedge$ & $\Delta / \& \Delta$ & $|V / \pi|$ & اضطراب جدايى & \\
\hline ra & $\wedge$ & $\Delta / \wedge \Delta$ & $\mid V / \Delta S$ & 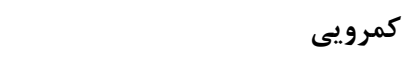 & \\
\hline TF & $\Delta$ & r/A & 1.199 & خود درونى شكننده & \\
\hline $11 \pi$ & Vr & $\Lambda / \pi \omega$ & $9 \% / r \Lambda$ & تعارض زناشويى والدين (نمره كل) & \multirow{4}{*}{ تعارض زناشويى } \\
\hline is & ru & $4 / 1$. & TN/DT & ويزكى هاى تعارض & \\
\hline kr & re & $\varphi /$. & Tr/VG & خودسرزنشى & \\
\hline rq & 19 & $r / \Lambda \Delta$ & $r T / l$. & ت ت تهديد & \\
\hline
\end{tabular}

هدفمند با حساسيت بين فردى و تعارض زناشويى والدين

نتايج جدول r نشان مىدهد كه اعتياد به اينترنت با

$$
\text { ارتباط منفى دارد ( ( • • (p). }
$$

حساسيت بين فردى و تعارض زناشويى والدين ارتباط مثبت و با كنترل هدفمند ارتباط منفى دارد. همرجنين كنترل 
جلدول ب - ماتريس همبستكى متغيرهاى اعتياد به ايتترنت، كنترل هدفمند، حساسيت بين فردى و تعارض زناشويى والدين در دانش آموزان شهر اردبيل

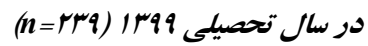

\begin{tabular}{|c|c|c|c|c|c|c|c|c|c|c|c|c|}
\hline$(I T)$ & (11) & $(1 \cdot)$ & (9) & (^) & $(\vee)$ & (9) & (b) & (f) & (广) & $(\tau)$ & (1) & متغيرهاى پِيشبين \\
\hline & & & & & & & & & & & 1 & حساسيت بين فردى (1) \\
\hline & & & & & & & & & & 1 & $\cdot / \wedge V_{* *}$ & آكاهى بين فردى (r) \\
\hline & & & & & & & & & 1 & $\cdot / V \mid$ *** & $\cdot \mid \Lambda \Lambda * * *$ & نياز به تأييد (r) \\
\hline & & & & & & & & 1 & $\cdot / V V$ 米* & $\cdot 19 \Lambda$ 米*** & $\cdot \mid \Lambda \Lambda * * *$ & اضطراب جدايى (f) \\
\hline & & & & & & & 1 & $\cdot / V \mathcal{F}_{* *}$ & $\cdot / V Y_{*} * *$ & $\cdot / V V_{* * *}$ & $\cdot \mid 91$ *** & كمرويى (ه) \\
\hline & & & & & & 1 & 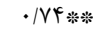 & $\cdot 199 \% *$ & $\cdot 199$ 米* & 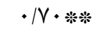 & $\cdot \mid \Lambda f_{* *}$ & خود درونى شكننده (9) \\
\hline & & & & & 1 & $\cdot / \Gamma \omega_{* * *}$ & $\cdot / T r_{* * *}$ & $\cdot / q_{*} * *$ & $\cdot / \Gamma V_{* * *}$ & $\cdot / \Gamma r * * *$ & $\cdot / \mathcal{F} \cdot \frac{*}{*}$ & تعارض زناشويى والدين (V) \\
\hline & & & & 1 & $\cdot \mid \Lambda r_{* * * *}$ & $\cdot / \Gamma \omega_{* * *}$ & $\cdot|r|$ 䄅䊅 & $\cdot / r \Delta * *$ & $\cdot / \pi r$ 䄅米 & $\cdot / \Gamma \Delta * * *$ & 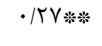 & ويزَكى هاى تعارض (^) \\
\hline & & & 1 & 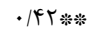 & $\cdot / V \Lambda$ **** & $\cdot / \pi \varphi_{* * *}$ & $\cdot / \Gamma \Lambda * *$ & $\cdot / \pi 9 * *$ & $\cdot / r \Lambda * * *$ & $\cdot / r \cdot * * *$ & $\cdot / \Gamma \cdot * * *$ & خود سر زنشى (9) \\
\hline & & 1 & $\cdot / \Gamma \Lambda * * *$ & $\cdot / \Gamma V$ 䄅* & $\cdot 199$ 䄅* & $\cdot / \Gamma \cdot * *$ & $\cdot / \Gamma \cdot * *$ & $\cdot /$ / & $\cdot / \Gamma V_{* * *}$ & $\cdot / \pi \mid * * *$ & $\cdot / \Gamma \Lambda$ 人** & تهديد (•) \\
\hline & 1 & $-\cdot / l f_{*}$ & $-\cdot / 1 \Delta_{*}$ & $-\cdot / 1$ & $-\cdot / / V_{*}^{*} *$ & $-\cdot / \Gamma V_{\text {䄅米 }}$ & $-\cdot / r$ 絭 &.$- / 14$ & $-\cdot / 1$ & $-\cdot / r \Delta * *$ & $-\cdot|r| * * *$ & كنترل هدفمند (II) \\
\hline 1 & $-\cdot \mid \varphi f * * *$ & $\cdot / \pi 1 * *$ & $\cdot|\Gamma| * *$ & $\cdot|r| * *$ & $\cdot / \pi \varphi_{\text {米* }}$ & $\cdot / \uparrow \wedge$ 米* & $\cdot / \Delta \cdot * *$ & $\cdot / \mathcal{E V} * *$ & $\cdot / \uparrow \wedge$ 䄅* & $\cdot \mid \Delta \wedge * * *$ & $\cdot \mid \Delta V$ 䄅䊑 & اعتياد به اينترنت (ז) \\
\hline
\end{tabular}

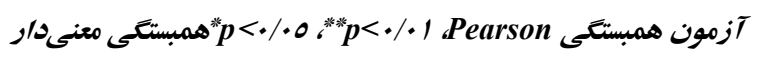

كه ارزشهاى تحمل به دست آمده براى متغيرها بالاى • //. هستند و نشان دهنده عدم وجود همخطى جند متغيرها است و همجنين مقدار عامل تورم واريانس به دست آمده براى متغيرها كوجىتر از • إ بودند كه نشان دهنده عدم همخطى جند گَانه بين متغيرها است. نمودار r، بارهاى استاندارد شده مدل :ثروهش را نشان مىدهد. در اين مطالعه تمام روابط حساسيت بين فردى و تعارض زناشويى و اعتياد به اينترنت با كنترل هدفمند (به غير از ارتباط مستقيم تعارض زناشويى والدين با كنترل هدفمند) در دانش آموزان معنى دار مىباشد (ه • • >p).
قبل از تحليل دادهها و براى اطمينان از اينكه دادههاى اين يزوهش مفروضههاى زيربنايى مدليابى معادلات ساختارى را برآورد مى كنند، جُند مفروضه اصلى معادلات ساختارى شامل دادههاى گمشده، نرمال بودن دادهها و همخطى جندگَانه مورد بررسى قرار گرفتند. در ״روهش حاضر، جهت نرمال بودن متغيرها از آزمون آمارى Kolmogorov-Smirnov داد كه دادهها داراى توزيع نرمال بودند (ه•|• (p) و همخطى جندكَانه بين متغيرها با استفاده از آماره تحمل و عامل تورم واريانس مورد بررسى قرار گرفت. نتايج نشان داد 


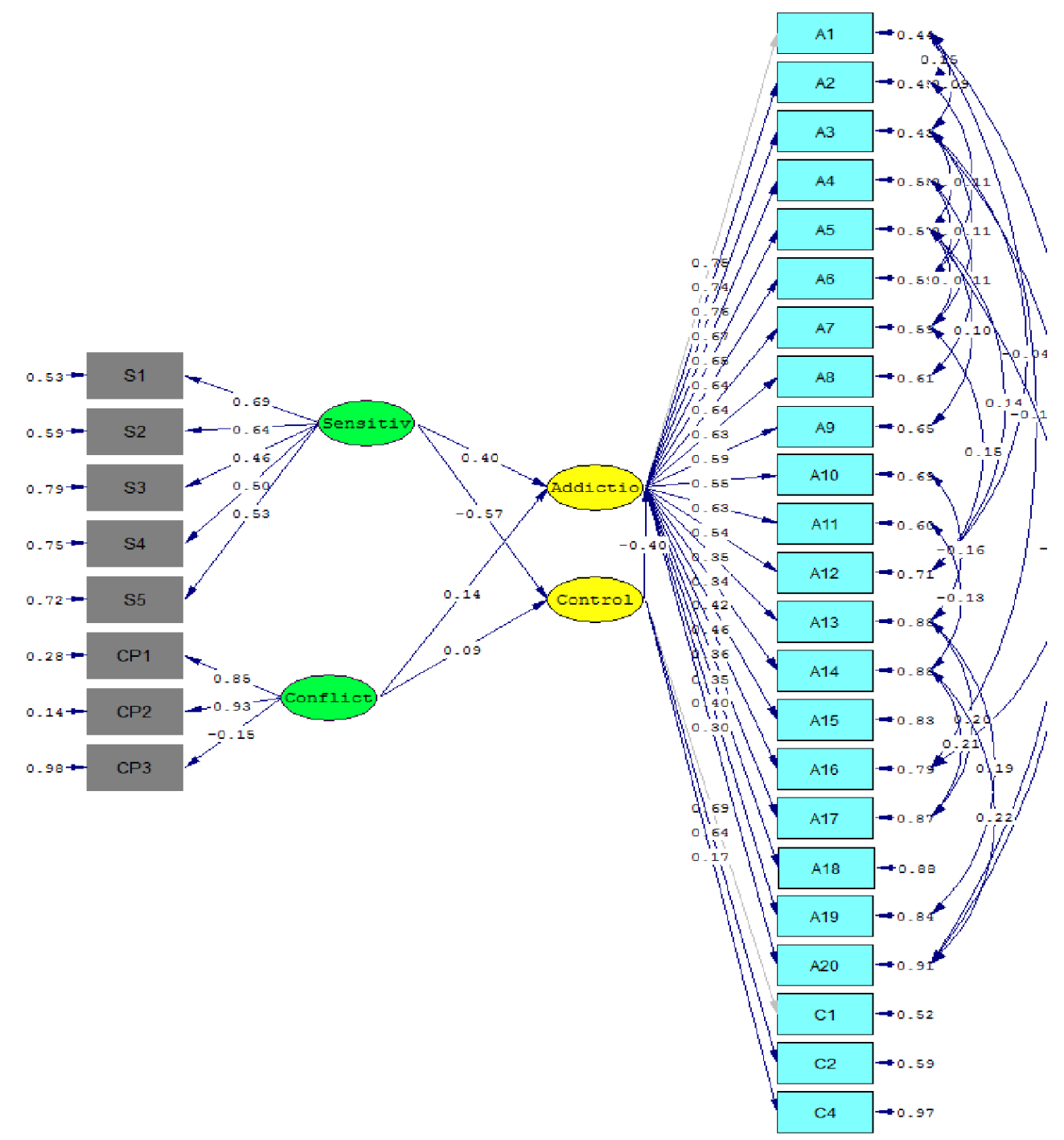

Chi-square=974.02, df=406, P-value=0.00000, RMBEA=0.077

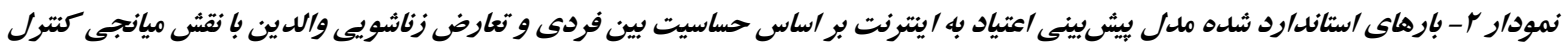

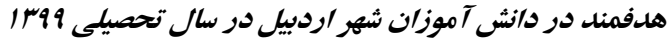

با توجه به نمودار سا، و معنادارى آماره T مربوط به هر يك رى كنترل هدفمند و تأثير تعارض زناشويى والدين بر از متغيرهاى يزوهش در سطح خطاى هـ/.، فرضيه يزوهش اعتياد به اينترنت تأييد مىشود. تأثير حساسيت بين فردى بر اعتياد به اينترنت با ميانجى - 


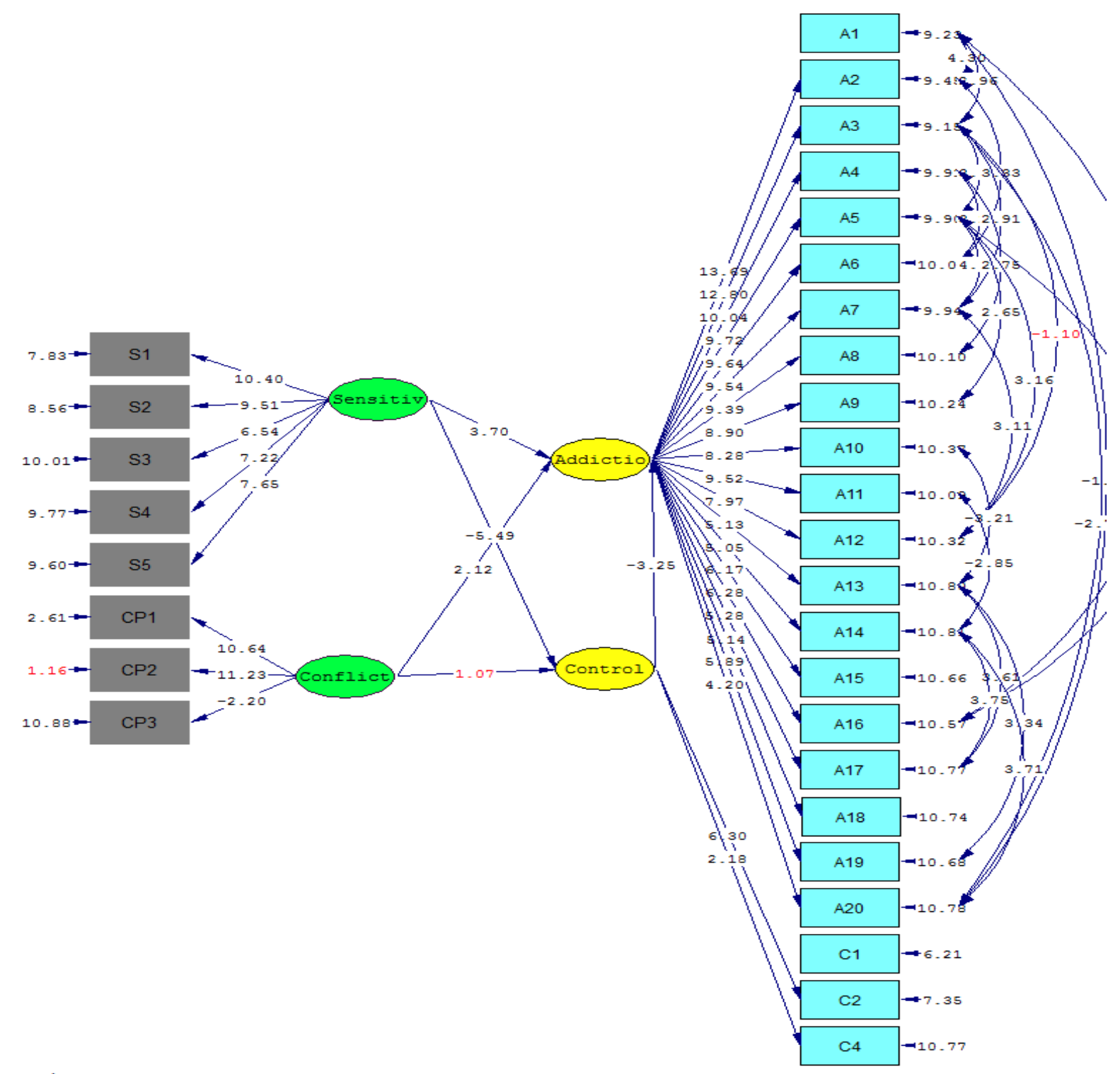

Chi-Square $=974.02, d f=406, P-$ value $=0.00000$, RMSEA $=0.077$

نمودار بر- نتايج تحليل محاسبه مقدار T مدل بيشبينى اعتياد به ايتترنت براساس حساسيت بين فردى و تعارض زناشويى والدين با نقش ميانجى كنترل

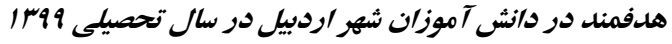

اينترنت •^/••--است. همرجنين با توجه به اطلاعات جدول ؟، ميزان تأثير غيرمستقيم حساسيت بين فردى بر اعتياد به

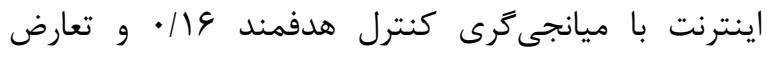
زناشويى والدين بر اعتياد به اينترنت با ميانجى

$$
\text { هدفمند وه • • • | بوده است. }
$$

با توجه به نمودار r و r و اطلاعات جدول r، تأثير مستقيم حساسيت بين فردى بر اعتياد به اينترنت • \&/•. حساسيت بين فردى بر كنترل هدفمند QV ••--، تعارض زناشويى والدين بر اعتياد به اينترنت f |f •، تعارض زناشويى والدين بر كنترل هدفمند 9 • ••، كنترل هدفمند بر اعتياد به 
ץ • أ مدليابى اعتياد به اينترنت بر اساس حساسيت بين فردى و تعارض زناشويى والدين ...

جدول بـ - ثاخصهاى برازندكى ملدل بيشبينى اعتياد به ايتترنت بر اساس حساسيت بين فردى و تعارض زناشويى والدين با نقش ميانجى كنترل

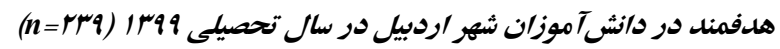

\begin{tabular}{|c|c|c|c|c|c|}
\hline نتيجه & Pقدار P P & مقدار T T T & ميزان اثر & & نأثيرات مستقيم \\
\hline تأييد شده & $\% r$ & $r / v \cdot$ & $\cdot / 4$ & اعتياد به اينترنت & حساسيت بين فردى \\
\hline تأييد شده & $.1 . .1$ & $-\infty / 4 q$ & $-\cdot / Q V$ & كنترل هدفمند & حساسيت بين فردى \\
\hline تأييد شده & . & $t / t$ & $\cdot / 14$ & اعتياد به اينترنت & تعارض زناشويى والدين \\
\hline تأييد نشده & $\cdot / 10$ & $1 / \cdot V$ & .1 .9 & كنترل هدفمند & تعارض زناشويى والدين \\
\hline تأييد شده & H & $-r / T \Delta$ & $-\cdot / \kappa$ & اعتياد به اينترنت & كنترل هدفمند \\
\hline نتيجه & 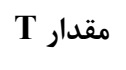 & & & \multicolumn{2}{|c|}{ تأثيرات غير مستقيم ميزان اثر } \\
\hline تأييد شده & t/Vq & $\cdot / \mathbb{k} \cdot x-\cdot / \mathcal{k} \cdot=\cdot / 1 \varepsilon$ & اعتياد به اينترنت & كنترل هدفمند & حساسيت بين فردى \\
\hline تأييد نشده & $1 / V V$ & $\cdot / \mid f_{X-} \cdot / q^{\prime}=\cdot / \cdot \Delta q$ & اعتياد به اينترنت & كنترل هدفمند & تعارض زناشويى والدين \\
\hline
\end{tabular}

بزرىتر از • • • • مىباشد. شاخصهاى كاى اسكوئر بهنجار شده ) (Normed chi-square index; CMIN/DF) و شاخص برازش مقايسهاى (Comparative fit index; CFI) در دامنه مورد قبول قرار دارد و مدل تدوين شده را مورد حمايت قرار مىدهند. از آنجا كه ريشه دوم ميانگين مربعات خطاى (Root mean squared error of approximation; برآورد RMSEA) طرفى بازه قابل قبول براى آن كمتر از ^• • • مىباشد، پِ لـ مى توان كفت مدل برازش شده مدل مناسبى است [YF].
جهت تعيين كفايت برازش الكَى ييشنهادى با دادهها شاخصهاى مذكور مقادير هر يك از اين شاخصها بين • و ا قرار دارد و مقادير نزديك و يا بيشتر از •9/ • نشانه مطلوب بودن مدل مىباشد. شاخص برازش مقايسهاى (Comparative fit index; CFI) شاخص برازش فزاينده (Incremental Fit Index; IFI) (Goodness of fit index; شاخص نيكويى برازش، شاخد 19F GFI) شاخص برازش هنجار شده مقتصد Parsimony Normed) كه مقدار Fit Index; PNFI)

\begin{tabular}{|c|c|c|c|c|c|c|}
\hline RMSEA & PNFI & IFI & GFI & CFI & CMIN/DF & شاخص \\
\hline$\cdot 1 \cdot v$ & $\cdot / \mathrm{VA}$ & .194 & .194 & .194 & $r / r q$ & مقدار محاسبه شده \\
\hline$<\cdot 1 \cdot 1$ & $>\cdot 10^{\circ}$ & $>.19$. & $>\cdot 19$. & $>.19$. & $1-r$ & سطح قابل قبول [rf] \\
\hline
\end{tabular}

ميانجى بحث نتايج معادلات ساختارى در يزوهش حاضر نشان داد كه يزوهش حاضر با هدف مدليابى اعتياد به اينترنت بر حساسيت بين فردى با اعتياد به اينترنت ارتباط مستقيم اساس حساسيت بين فردى و تعارض زناشويى والدين با 
شناختى و انخَيزى در رابطه بين اعتياد به اينترنت و حساسيت بين فردى دانشآموزان تأثير تعديل كنندهاى داشته باشد. از نظر مكانيسمهاى شناختى، افرادى كه كنترل بالايى دارند ممكن است بتوانند جهت و مدت توجه خود را تنظيم كرده و رفتار يیش از قدرت را مهار كنند (مانند بررسى ميزان مصرف اينترنت) و همجنين براى پاسخَّيى به خواستههاى موقعيتى توجه خود را به وظايفى كه بايد انجام دهند تغيير دهند. از نظر سازوكارهاى انخيزشى، تصور مىشود كه افراد با كنترل و هدفمندى بالا در شروع، حفظ و تنظيم انكيزه خود و انجام فعاليتهاى هدايت شونده مانند كارهاى دانشعاهى بهتر عمل مى كنند [هـ] بنابراين دانشآموزانى كه كنترل هدفمندى بيشترى دارند ممكن است بتوانند وسوسه رضايت فورى ناشى از استفاده از اينترنت مانند ارضاى نيازهاى مربوط به ارتباطات را به صورت آنلاين مهار كنند و انكيزه بيشرفت خود را حفظ كنند؛ بنابراين ممكن است اثر اعتياد به اينترنت در به تعويق انداختن غيرمنطقى كاهش يابد. نتايج معادلات ساختارى ما حاكى از آن است كه تعارضات زناشويى والدين به طور قابل توجهى با اعتياد دانشآموزان به اينترنت ارتباط دارد. اين يافته با جندين مطالعه Ko و همكاران [r/ [1]، Wu و همكاران [11] و Yang و همكاران [ [1] همخوان مىباشد. يافتههاى ما همراه با اين يافتههاى قبلى، همرجنين نشان داد كه آن دسته از نوجوانان و دانشآموزانى كه در يك خانواده با اختلاف نظر رشد كردهاند
دارد. اين نتايج با يافتههاى Chen و همكاران [ع] و Hou و همكاران [V] مبنى بر اين كه بين اعتياد به اينترنت و مشكلات بين فردى همبستگى مثبت معنى دارى وجود دارد و نوجوانان داراى اعتياد به اينترنت مشكلات بين فردى بيش ترى نشان دادند و احتمالاً روابط بين فردى ضعيف را حفظ مى كنند كه اين امر ممكن است به احساس تنهايى بيشتر در آنها منجر شود، همخوان مىباشد. در تبيين اين فرض مىتوان كَفت دانشآموزان در معرض خطر اعتياد به اينترنت بيشتر اوقات فراغت خود را به بازىهاى آنلاين يا جت آنلاين مى گذرانند. در نتيجه، آنها وقت ندارند كه در دنياى واقعى با افرادى مانند خانواده و دوستانشان تعامل داشته باشند. اين فعاليتها منجر به مشكلات بين فردى مىشود زيرا اين نوجوانان در دنياى مجازى راحتترند، جايى كه مىتوانند احساسات و افكار خود را به صورت ناشناس بيان كنند. نتايج معادلات ساختارى نشان داد كه حساسيت بينفردى بر اعتياد به اينترنت با ميانجىگرى كنترل هدفمند اثر غيرمستقيم دارد. اين نتايج با يافتههاى Chriki و همكاران [ Cain و و همكاران [r/r] همخوان مىباشد. در تبيين اين فرض مىتوان كفت كه مشكلات بين فردى مانند درونگرايى، مشكلات اجتماعى و مهارتهاى ضعيف ارتباط جهره به جهره، اغلب منجر به اعتياد به اينترنت مىشود. روابط مبتنى بر اينترنت گزينهاى ايمن براى فرار از طرد و نكرانىهاى احتمالى تماسهاى بين فردى در زندگى واقعى براى افرادى كه داراى مشكلات فوق هستند، ارائه مى دهد. به طور خاص، كنترل هدفمند مىتواند از طريق مكانيسمهاى 
شديد با شريك زندگى خود باشند، ممكن است نتوانند مراقبت و نظارت مناسب را انجام دهند [rv]. سرانجام، دانشآموزانى كه در خانه تعارض را تجربه مىكنند ممكن است دريابند كه غوطهور شدن در دنياى اينترنت مجازى فرار از دركيرى است. آنها همجنين ممكن است دريابند كه

قادر به حمايت گرفتن در دنياى اينترنت هستند [م؟]. نتايج معادلات ساختارى در يزوهش حاضر نشان داد كه كنترل هدفمند با اعتياد به اينترنت ارتباط مستقيم دارد. اين نتايج با يافتههاى Wang و همكاران [19] و Liu و همكاران مبنى بر اينكه بين اعتياد به اينترنت و كنترل هدفمند ارتباط منفى و معنىدارى وجود دارد و كنترل هدفمند ضعيف تا حدى مىتواند استفاده مشكلساز نوجوانان به ويزه در بين زِران از اينترنت را توضيح دهد همخوان مىباشد

در تبيين اين فرض مىتوان اظهار داشت كه كنترل هدفمند به طيف گستردهاى از نتايج سازگارى، از جمله شايستگى اجتماعى، پاسخَّويى همدلانه و درونىسازى رفتار مربوط مىشود. از افراد با كنترل هدفمندى بالا انتظار مىرود كه در مقابله يا از بين بردن احساسات منفى خود و كاهش اثر ناخواسته بالقوه استفاده از اعتياد به اينترنت بر احساسات ذهنى خود موفقتر باشند. معمولاً تصور مىشود كه آنها از استقامت، اراده و انعطافيذيرى خوبى برخوردار هستند [qץ]. بنابراين، حتى اتر دانشآموزان با كنترل هدفمندى زياد استفاده بيشازحد از اينترنت داشته باشند با مهارتهاى
ممكن است در معرض خطر بيشترى براى اعتياد به اينترنت باشند. نظريه سيستم خانواده Bowen، خانواده را به عنوان يك واحد عاطفى اساسى در نظر مى گيرد. اين نظريه فرض مى كند كه فشار ناشى از دركيرى عاطفى بين هر دو عضو خانواده مىتواند به يك مثلث خانوادگى تبديل شود كه حداقل يك واحد عاطفى پايدار است كه توسط پٍر، مادر و كودى تشكيل مىشود [[.1]. تعارضات زناشويى، به عنوان يك عامل استرسزاى مهم در خانواده، ممكن است باعث رفتارهاى مشكل آفرين فرزندان شود. به طور خاص، مطالعات تجربى نشان داده است كه تعارضات زناشويى والدين مىتواند بر اينترنت جوانان تأثير بخذارد. به عنوان مثال، جندين مطالعه نشان داده است كه درگيرى زناشويى مىتواند به طور قابل توجهى علائم رفتار آنلاين اعتيادآور را پيشبينى كند [^]. در راستاى اين يافتههاى تجربى، در يك بررسى اخير نيز بر نقش يك محيط خانوادگى متعارض بر اعتياد جوانان به اينترنت تأكيد شده است [عץ]. آنها دريافتند كه جوانان مبتلا به اعتياد به اينترنت احتمالاً از مشكلات خانوادگى ناكارآمد از جمله تعارضات زناشويى والدين رنج مىبرند. به دنبال اين يافتهها ما فرض كرديم كه درگيرى زناشويى والدين مىتواند اعتياد جوانان به اينترنت را به صورت منفى ييشبينى كند. همرجنين ممكن است دانشآموزانى كه تعارض والدين نسبتاً بالايى را درك مى كنند از فرزند يرورى كرم يا حمايت كمترى برخوردار باشند. اخر والدين دركير مشاجرات مكرر يا 
گسترداى براى نوجوانان و دانش آموزان ايجاد شود و هم-

جنين برنامههاى مشاورهاى براى ارائه به نوجوانان داراى

اعتياد به اينترنت تدوين شود. همرجنين، آموزش مهارتهاى بين فردى و راهبردهاى حل مسأله براى دانشآموزان و والدين نوجوانان داراى اعتياد به اينترنت انجام شود. تشكر و قدردانى

اين يزوهش با حمايت مالى معاونت يزوهشى دانشعاه

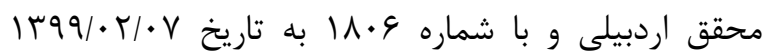
انجام گرفت. به اين وسيله از كليه همكارىهاى مشفقانه مدير، مشاور و معلمان مدارس شهرستان اردبيل و كليه دانشآموزان شركت كننده در يزوهش و همرجنين از دانشعاه محقق اردبيلى بابت حمايت مالى از اين يزوهش نهايت قدردانى مىشود.
تنظيم هيجان بالاى كه دارند مىتوانند رفتار خود را مديريت

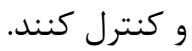

استفاده صرف از يرسشنامه براى ارزيابى متغيرها به ويزه

ارزيابى ميزان استفاده از اينترنت و محدود بودن جامعه آمارى به شهر اردبيل دو محدوديت عمده مطالعه حاضر بود كه براى دستيابى به نتايج بهتر از روشهاى اندازهيرى متفاوت (مصاحبه بالينى) و نه صرفاً از برسشنامه و اجراى يزوهش در ديخر مناطق جغرافيايى بيشنهاد مى گردد.

\section{نتيجهل}

به طور كلى نتايج يزوهش حاضر نشان داد كه بين حساسيت بين فردى و تعارض زناشويى والدين و كنترل هدفمند با اعتياد به اينترنت ارتباط وجود دارد. لذا توصيه مىشود فعاليتهاى فرهنگى و اوقات فراغت سالم و

\section{References}

[1] Young K. The evolution of internet addiction disorder. J Psycho Behav Econom 2017; 29(2): 3-18.

[2] Černja I, Vejmelka L, Rajter M. Internet addiction test: Croatian preliminary study. $J$ BMC psychiatry 2019; 19(1): 1-11.
[3] Lipman RS, Covi L, Shapiro AK. The Hopkins Symptom Checklist (HSCL): factors derived from the HSCL-90. J Affect Disord 1979; 1(1): $9-24$.

[4] Babadi-Akashe Z, Zamani BE, Abedini Y, Akbari H, Hedayati N. The relationship between 
mental health and addiction to mobile phones among university students of Shahrekord Iran. $J$ Ment Health Addict 2014; 6(4): 93-9.

[5] Otsuka Y, Kaneita Y, Itani O, Tokiya M. Relationship between Internet Addiction and Poor Mental Health among Japanese Adolescents. J Iran J Public Health 2020; 49(11): 2069-77.

[6] Chen R, Liu J, Cao X, Duan S, Wen S, Zhang S, et al. The relationship between mobile phone use and suicide-related behaviours among adolescents: the mediating role of depression and interpersonal problems. J Affect Disord 2020; 15(269): 101-7.

[7] Hou J, Jiang Y, Chen S, Hou Y, Wu J, Fan N, et al. Cognitive mechanism of intimate interpersonal relationships and loneliness in internet-addicts: An ERP study. J Addict Behav 2019; 10(1): 1-11.

[8] De Leo JA, Wulfert E. Problematic Internet use and other risky behaviors in college students: An application of problem-behavior theory. $J$ Psychol Addict Behav 2013; 27(1): 133-41.
[9] Kalaitzaki AE, Birtchnell J. The impact of early parenting bonding on young adults' Internet addiction, through the mediation effects of negative relating to others and sadness. $J$ Addict Behav 2014; 39(3): 733-6.

[10] Bowen M. Theory in the practice of psychotherapy. Family therapy: Theory and practice. $1976 ; 4(1)$ : 2-90.

[11] Wu CST, Wong HT, Yu KF, Fok KW, Yeung $\mathrm{SM}$, Lam $\mathrm{CH}$, et al. Parenting approaches, family functionality, and internet addiction among Hong Kong adolescents. BMC pediatrics 2016; 16(1): 1-10.

[12] Yang X, Zhu L, Chen Q, Song P, Wang Z. Parent marital conflict and Internet addiction among Chinese college students: The mediating role of father-child, mother-child, and peer attachment. J Comput Hum Behav 2016; 59(2): 221-9.

[13] Ko CH, Wang PW, Liu TL, Yen CF, Chen CS, Yen JY. Bidirectional associations between family factors and I nternet addiction among 
adolescents in a prospective investigation. $J$ Psychiatry Clin Neurosci 2015; 69(4): 192-200.

[14] Gao T, Meng X, Qin Z, Zhang H, Gao J, Kong $\mathrm{Y}$, et al. Association between parental marital conflict and Internet addiction: A moderated mediation analysis. J Affect Disord 2018; 240: 27-32.

[15] Zhou Q, Main A, Wang Y. The relations of temperamental effortful control and anger/frustration to Chinese children's academic achievement and social adjustment: A longitudinal study. J Educ Psychol 2010; 102(1): 180-96.

[16] Anderson EL, Steen E, Stavropoulos V. Internet use and Problematic Internet Use: A systematic review of longitudinal research trends in adolescence and emergent adulthood. Int $J$ Adolesc Youth 2017; 22(4): 430-54.

[17] Jiang Z, Zhao X. Brain behavioral systems, selfcontrol and problematic mobile phone use: The moderating role of gender and history of use. $J$ Pers Individ Dif 2017; 106(2): 111-16.
[18] Cerruti R, Spensieri V, Presaghi F, Valastro C, Fontana A, Guidetti V. An exploratory study on Internet addiction, somatic symptoms and emotional and behavioral functioning in schoolaged adolescents. J Neuropsychiatry Clin 2017; (6): 374-83.

[19] Wang L, Tao T, Fan C, Gao W, Wei C. The association between Internet addiction and both impulsivity and effortful control and its variation with age. J Addict Res Theory 2017; 25(1): 83-90.

[20] Liu R-D, Hong W, Ding Y, Oei TP, Zhen R, Jiang S, et al. Psychological distress and problematic mobile phone use among adolescents: the mediating role of maladaptive cognitions and the moderating role of effortful control. J Front Psychol 2019; 10(1); 1-9.

[21] Chriki LS. The Interaction of Rejection Sensitivity and Effortful Control in the Prediction of Interpersonal Dysfunction: Doctoral dissertation, The Ohio State University; 2012. 


$$
\text { 1 • ا مدليابى اعتياد به اينترنت بر اساس حساسيت بين فردى و تعارض زناشويى والدين ... }
$$

[22] Cain NM, Meehan KB, Roche MJ, Clarkin JF, De Panfilis C. Effortful control and interpersonal behavior in daily life. $J$ Pers Assess 2018; 101(1): 315-25.

[23] Przepiorka A, Blachnio A, Miziak B, Czuczwar S. Clinical approaches to treatment of Internet addiction. J Pharmacological Reports. 2014; 66(2): 187-91.

[24] Homan AH. Structural Equation Modeling Using LaserL Software. Tehran: Samt; 2014.[Farsi].

[25] Young KS. Internet addiction: The emergence of a new clinical disorder. $J$ Cyberpsychol Behav Soc Netw 1998; 1(3): 237-44.

[26] Young KS , Rogers R. Rodgers RC. The relationship between depression and Internet addiction. J Cyberpsychol Behav 1998; 1(1): 2528.

[27] Widyanto L, McMurran M. The psychometric properties of the internet addiction test. $J$ Cyberpsychol Behav Soc Netw 2004; 7(4): 44350.
[28] Alavi S, Eslami M, Meracy M, Najafi M, Jannatifard F, Rezapour H. Psychometric properties of Young internet addiction test. $J$ Inter Behav Sci 2010; 4(3): 183-9. [Farsi].

[29] Rothbart MK, Ahadi SA, Evans DE. Temperament and personality: origins and outcomes. J Pers Soc Psychol 2000; 78(1): 35122.

[30] Basharpoor S. The relationship between cognitive emotion regulation and intelligent control with the severity of dependence and craving in people with substance abuse. $J$ Substance Abuse Research Addiction 2013; 7(28): 131-6. [Farsi].

[31] Boyce P, Parker G. Development of a scale to measure interpersonal sensitivity. Aust $N Z$ J Psychiatry 1989; 23(3): 341-51.

[32] Narimani M, Porzoor P, Basharpoor S. Comparison of interpersonal sensitivity and emotional balance in students with and without specific learning disorder. $J$ Learning disabilities 2015; 5(1): 125-41. [Farsi]. 
[33] Grych JH, Seid M, Fincham FD. Assessing marital conflict from the child's perspective: The Children's Perception of Interparental Conflict Scale. J Child development 1992; 63(3): 558-72.

[34] Salavati S, Shokri O. A psychometric analysis of the Young Children's Appraisals of Interparental Conflict Scale. Developmental Psychology: J Iranian Psychologists 2015; 11(44): 379-89.

[35] Ferreira T, Cadima J, Matias M, Leal T, Matos PM. Teacher-child dependency in preschool: links with teacher-child closeness, conflict and children's effortful control.Attachment \& Human Development. J Attach Hum Dev 2020; 22(1): 1-16.

[36] Li W, Garland EL, Howard MO. Family factors in Internet addiction among Chinese youth: A review of English-and Chinese-language studies. J Comput Hum Behav 2014; 31: 393-411.

[37] Masarik AS, Conger RD. Stress and child development: A review of the Family Stress Model. J Curr Opin Psychiatry 2017; 13(2): 8590.

[38] Hsieh Y-P, Shen AC-T, Wei H-S, Feng J-Y, Huang SC-Y, Hwa H-L. Internet addiction: A closer look at multidimensional parenting practices and child mental health. $J$ Cyberpsychol Behav Soc Netw 2018; 21(12): 768-73.

[39] Zhang J, Li D, Ahemaitijiang N, Peng W, Zhai B, Wang Y. Perceived school climate and delinquency among Chinese adolescents: A moderated mediation analysis of moral disengagement and effortful control. $J$ Child Youth Serv Rev 2020; 116(1): 105-253.. 
• • • • مدل يابى اعتياد به اينترنت بر اساس حساسيت بين فردى و تعارض زناشويى والدين ...

\title{
Modeling Internet Addiction Based on Interpersonal Sensitivity and Parents' Marital Conflict with the Mediating Role of Effortful Control in Students of Ardabil City in the 2020 Academic Year: A Descriptive Study
}

\author{
$\underline{\text { S. Basharpoor }}{ }^{1}$, S. Ahmadi ${ }^{2}$, F. Heidari ${ }^{3}$
}

Received:27/09/2020 Sent for Revision:04/11/2020 Received Revised Manuscript:09/12/2020 Accepted: 12/12/2020

Background and Objectives: Sensitivity to interpersonal interactions and marital conflicts plays an important role in the tendency of children to become addicted to the Internet. The aim of this study was to model Internet addiction based on interpersonal sensitivity and parents' marital conflict with the mediating role of effortful control in students. Materials and Methods: The present research method is descriptive. The statistical population was all first and second year high school students in Ardabil in 2020. A sample of 239 people from this population was selected by available sampling method and answered the questionnaires of Internet addiction, Effortful Control, Interpersonal Sensitivity and Parents' Marital Conflict. Data were analyzed using Pearson's correlation coefficient and structural equation modeling.

Results: The results showed that Internet addiction was positively correlated with the total score of interpersonal sensitivity $(\mathrm{r}=0.57, \mathrm{p}<0.001)$ and parents' marital conflict $(\mathrm{r}=0.36, \mathrm{p}<0.001)$ and had a negative correlation with effortful control $(\mathrm{r}=-0.44, \mathrm{p}<0.001)$. Effortful control was also negatively related to the total score of interpersonal sensitivity $(\mathrm{r}=-0.21, \mathrm{p}<0.001)$ and parents' marital conflict $(\mathrm{r}=-0.17, \mathrm{p}<0.001)$. Model fit indices also confirmed the effect of interpersonal sensitivity and parents' marital conflict on Internet addiction with the mediating role of effortful control.

Conclusion: The results of this research can be used in creating applications and workshops for adolescents who are addicted to the Internet as well as in the prevention of Internet addiction.

Key words: Internet Addiction, Effortful control, Interpersonal sensitivity, Parents' marital conflict, Students, Ardabil

Funding: This study was funded by University of Mohaghegh Ardabili.

Conflict of interest: None declared.

Ethical approval: The Ethics Committee of Ardabili University of Medical Sciences approved the study (IR.ARUMS.REC.1399.407).

How to cite this article: Basharpoor S, Ahmadi S, Heidari F. Modeling Internet Addiction Based on Interpersonal Sensitivity and Parents' Marital Conflict with the Mediating Role of Effortful Control in Students of Ardabil City in the 2020 Academic Year: A Descriptive Study. J Rafsanjan Univ Med Sci 2021; 19 (10): 1053-70. [Farsi]

1- Prof., Department of Psychology, Faculty of Educational Sciences and Psychology, University of Mohaghegh Ardabili, Ardabil, Iran ORCID: 0000-000229202605

(Corresponding Author) Tel: (045) 31505622, Fax: (045) 31505622,E-mail: basharpoor_sajjad@uma.ac.ir

2- PhD Student of Psychology, School of Educational Sciences and Psychology, University of Mohaghegh Ardabili, Ardabil, Iran ORCID: 0000-0003-0189-9575

3- PhD Student of Psychology, School of Educational Sciences and Psychology, University of Mohaghegh Ardabili, Ardabil, Iran ORCID: 0000-0001-7501-5758

دوروه 19، شماره ·1، سال 99 199

مجله دانشگاه علوم يزشكى رفسنجان 